\title{
Role of dietary antioxidants in the prevention of in vivo oxidative DNA damage
}

\author{
M. S. Cooke*, M. D. Evans, N. Mistry and J. Lunec \\ Oxidative Stress Group, Division of Chemical Pathology, University of Leicester, Robert \\ Kilpatrick Clinical Sciences Building, Leicester Royal Infirmary, University Hospitals of \\ Leicester NHS Trust, Leicester LE2 7LX, UK
}

\begin{abstract}
Epidemiological evidence consistently shows that diets high in fresh fruit and vegetables significantly lower cancer risk. Given the postulated role of oxidative DNA damage in carcinogenesis, the assumption has been made that it is the antioxidant properties of food constituents, such as vitamin $\mathrm{C}$, $\mathrm{E}$ and carotenoids, which confer protection. However, epidemiological studies with specific antioxidants, either singly or in combination, have not, on the whole, supported this hypothesis. In contrast, studies examining the in vitro effect of antioxidants upon oxidative DNA damage have generally been supportive, in terms of preventing damage induction. The same, however, cannot be said for the in vivo intervention studies where overall the results have been equivocal. Nevertheless, recent work has suggested that some dietary antioxidants may confer protective properties through a novel mechanism, unrelated to their conventional free-radical scavenging abilities. Upregulation of antioxidant defence, xenobiotic metabolism, or DNA-repair genes may all limit cellular damage and hence promote maintenance of cell integrity. However, until further work has clarified whether dietary supplementation with antioxidants confers a reduced risk of cancer and the mechanism by which this effect is exerted, the recommendation for a diet rich in fruit and vegetables remains valid empirically.
\end{abstract}

\section{Antioxidants: Diet: DNA damage: Free radicals}

\section{Introduction}

In the simplest terms, an antioxidant may be defined as a substance which, when present in small quantities compared with the substrate, prevents or delays the oxidation of that substrate (Halliwell \& Gutteridge, 1989). Reactive oxygen species (ROS) comprise a group of potentially reactive Ocontaining molecules or free radical species, such as superoxide $\left(\mathrm{O}_{2}{ }^{--}\right)$, hydroxyl radical $\left(\mathrm{HO}^{\circ}\right)$,

\footnotetext{
Abbreviations: 8-oxodA, 8-oxo-2'-deoxyadenosine; 8-oxodG, 8-oxo-2'-deoxyguanosine; dC-glyoxal, deoxycytidine-glyoxal adduct; EC, electrochemical detection; PBL, peripheral blood lymphocyte; PBMC, peripheral blood mononuclear cell; ROS, reactive oxygen species; $\mathrm{T}<>\mathrm{T}$, thymine dimer.

*Corresponding author: Dr M. S. Cooke, fax +44 116 2525887, email msc5@le.ac.uk
} 
hydrogen peroxide, singlet oxygen $\left({ }^{1} \mathrm{O}_{2}\right)$ and hypochlorite $\left({ }^{-} \mathrm{OCl}\right)$. Potential sources of cellular ROS include the generation of $\mathrm{O}_{2}{ }^{--}$by 'electron leakage' from the mitochondrial, and other, electron transport chains, neutrophil or macrophage respiratory burst activities, oxidase activities and arachidonic acid metabolism (for reviews, see Janssen et al. 1993; Evans et al. 1997). Spontaneous or enzymically-catalysed dismutation of $\mathrm{O}_{2}{ }^{--}$can lead to the production of hydrogen peroxide, which in turn, through the Haber-Weiss reaction, can yield the highly reactive HO*. Other important radicals and reactive species, such as lipid hydroperoxides, endoperoxides and reactive aldehydes may arise from autocatalytic lipid peroxidation, following the interaction of ROS with lipids, although such products may also derive from the synthesis of prostaglandins, leukotrienes and thromboxanes (Chow, 1988). It is accepted that whilst all these ROS are 'kept in check' by enzymic and non-enzymic defences, a little 'background' damage to cellular biomolecules is inevitable. However, oxidative stress, arising from the imbalance of pro-oxidative and anti-oxidative processes, in favour of the former, invariably leads to the significant modification of DNA (for reviews, see Marnett, 2000) generating a multitude of lesions such as 8-oxo- $2^{\prime}$ deoxyguanosine (8-oxodG) and 8-oxo-2'-deoxyadenosine (8-oxodA; Dizdaroglu, 1991). The subject of much study has been 8-oxodG, given its ease of formation and mutagenic potential.

A broad spectrum of techniques are available for the analysis of oxidative DNA damage. HPLC with electrochemical detection (EC) was the first method used for the routine analysis of 8-oxodG (Floyd et al. 1986) and use of this technique remains in a large number of laboratories, in part, due to its versatility. HPLC-EC has been applied to the analysis of 8-oxodG in various biological matrices, most notably, DNA (Floyd et al. 1986) and urine (Shigenaga et al. 1989). Antibodies to oxidative DNA damage were first developed as part of a pre-purification step before HPLC-EC (Kasai \& Nishimura, 1986), before becoming an optional technique for the measurement of DNA, serum and urinary 8-oxodG, in its own right (Cooke et al. 1998; Evans et al. 2000). Measurement, and identification, of oxidative DNA lesions other than 8oxodG was provided by the application of GC-MS (Dizdaroglu, 1991). A technique frequently used in toxicological studies for measuring DNA strand breaks, and more recently applied to the field of oxidative stress, is single cell gel electrophoresis, or Comet assay (Angelis et al. 1999). However, to tailor the technique for oxidative DNA damage, lesion-specific endonucleases need to be incorporated into the assay.

Measurement of nucleic acid markers of oxidative stress is not without its problems. The very process of DNA extraction from isolated cells has been reported to artifactually elevate levels of oxidative damage (Halliwell, 1998), which will have an effect irrespective of the method used. As this issue is fundamental to so many of the techniques, an organisation known as the European Standards Committee on DNA Damage (ESCODD), and comprising many research groups throughout Europe, has set itself the task of addressing this problem. Clearly, methods which do not require DNA extraction before analysis, such as immunochemical or Comet assays, can circumvent this issue. However, accurate quantification of the number of modified deoxynucleosides, per native deoxynucleoside is largely impossible. Furthermore, to be specific for oxidative DNA damage the Comet assay, as mentioned earlier (p. 20), requires the introduction of repair enzymes. Whilst the specificity of the repair enzymes (primarily formamidopyrimadine glycosylase protein and endonuclease III) has been characterised, the effect of factors, such as DNA-related proteins, cofactors, effect of lesion clusters and DNA conformation, upon enzyme efficiency as applied to the Comet assay, has not been fully investigated.

Chromatographic methods, such as HPLC-EC and GC-MS are perhaps better suited to 'absolute quantification', although both have their associated 'weaknesses', largely associated with sample workup. HPLC-EC is regarded by some to be the simplest, reliable method for 
measurement of a small number of lesions, principally 8-oxodG (Cadet et al. 1998), although the assay's limit of detection has, more recently, been brought into question (Lunec et al. $2000 \mathrm{~b}$ ). Criticism of the GC-MS approach has primarily been aimed towards the artifactual oxidation of native bases during the derivatisation step which, it has been suggested, may be overcome by HPLC-prepurification (Cadet et al. 1998). In stark contrast, a thorough review of the literature by Dizdaroglu (1998) illustrated that such criticisms of GC-MS may be unfounded, based upon comparisons of very different experimental procedures. Furthermore prepurification is said to be unnecessary when derivatisation is performed using a more refined protocol, in the absence of oxygen or at room temperature (Dizdaroglu, 1998). Whilst different research groups strongly advocate one technique, or the other, there does appear to be some agreement over an approach which, through liquid chromatography, coupled with tandem MS, avoids the need for sample derivatisation and combines this with the specificity and sensitivity of MS (Ravanat et al. 1998; Podmore et al. 2000).

Immunochemical methods are ideally suited to the detection of lesions in complex biological matrices, with their simplicity aiding automation and high throughput analyses (for comprehensive reviews of the benefits and drawbacks of immunochemical techniques, see Cooke $\&$ Lunec, 2002). However, comparison of antibody and HPLC-EC methods for the analysis of urinary 8-oxodG has revealed a discrepancy between the two techniques, although both techniques show good intra- and inter-laboratory agreement (Cooke et al. 2000). Explanation for this observation may derive from (1) possible cross-reactivity of the antibody with 8-oxoguanosine, present in the urine and also a perfectly acceptable marker of oxidative stress, and/or (2) urinary 8-oxodG being present in oligomers which are unavailable for detection by HPLC-EC. Evidence for the latter is increasing and suggests that these lesion-containing oligomers may derive from nucleotide excision repair (Cooke et al. 2001).

Many proponents of the hypothesis for the role of free radicals in disease acknowledge that oxidative DNA lesions are likely to participate in the pathogenesis of cancer, as well as many chronic and degenerative diseases. In particular, 8-oxo-guanine has been a focus of these studies, arising in part from the relative abundance of techniques available to measure this lesion and its potential biological importance (reviewed in Table 1; MS Cooke, MD Evans and J Lunec, unpublished results). The interest in dietary antioxidants, as a potentially simple means to modulate risk of disease development, is therefore obvious. Although many dietary compounds may be considered to have antioxidant properties, such as vitamin D (Chatterjee, 2001), unless they have been applied in human intervention studies of oxidative DNA damage, we have considered them outside the remit of this review.

\section{Nutritional antioxidants: source and function}

The human diet contains important micronutrients, such as vitamin $\mathrm{C}$ (ascorbate), vitamin $\mathrm{E}$ (tocopherols) and carotenoids, essential for the maintenance of human health. As such, the dietary route is a primary means of modulating endogenous antioxidant protection. Whilst these compounds are often referred to as antioxidants, as defined in the introduction, this may not be their primary function in vivo (Sies \& Stahl, 1995). Indeed, as will become apparent, they may not have a solely antioxidant effect. Evidence in vitro suggests that many of these compounds can directly react with oxidants and free radicals (i.e. act as scavengers) and are sacrificial targets for more critical biomolecules such as DNA. Many of these molecules may alter cellular antioxidant defence in more subtle ways, for example through the induction of DNA repair processes or enzymic antioxidant defence at the gene level. 
Table 1. Experimental evidence for the role of 8-oxo-guanine in the pathogenesis of various diseases

Pathological condition Oxidative DNA lesion levels

\section{Cancer}

ALL

Adult T cell leukaemia and lymphoma

Invasive ductal carcinoma

Primary breast cancer

Colorectal cancer

Gynaecological cancers

Cervical cancer

RCC

SCC

Small cell carcinoma

Lung cancer

Arsenic-related skin neoplasms

Breast, rectal and colon cancer

Assorted cancers
Lymphocyte DNA lesion levels significantly $(P<0.05)$ elevated in ALL compared with control subjects (Stentürker et al. 1997)

Urinary lesion levels elevated $(P<0.05)$ compared with controls (Honda et al. 2000)

Levels of lesions significantly $(P \leq 0.05)$ increased compared with calf thymus DNA (Malins \& Haimanot, 1991)

Significantly elevated levels of lesion $(P<0.001)$ in malignant breast tissue; also levels significantly greater $(P=0.007)$ in oestrogen receptor positive (ORP) $v$. ORP negative malignant tissue (Mussarat et al. 1996)

Significantly higher $(P<0.0001)$ levels of lesion in tumour $v$. non-tumour tissue (Matsui et al. 2000)

Significantly elevated levels of lesion $(P<0.005)$ in tumour tissue compared with normal mucosa (Oliva et al. 1997)

Significant correlation between lymphocyte lesion levels and colorectal cancer deaths in men $(r 0.91, P<0.05$; Collins et al. 1998a)

Levels significantly higher $(P \leq 0.05)$ in patients with gynaecological cancer compared with control subjects (Yamamoto et al. 1996)

Levels of lesion significantly increased $(P<0.001)$ in low-grade and high-grade levels of dysplasia, compared with normal (Romano et al. 2000)

Levels of lesion significantly higher $(P<0.0005)$ in RCC $v$. noncancerous tissue (Okamoto et al. 1994)

Levels elevated in tumour tissue of all SCC patients $v$. controls (Jaruga et al. 1994)

Elevated lesion compared with controls $(P<0.05)$ (Erhola et al. 1997)

Lymphocyte DNA levels of lesion significantly elevated $(P<0.05)$ compared with controls (Vulimiri et al. 2000)

Elevated levels of lesions in lung cancer compared with normal lung tissue from control individuals (Inoue et al. 1998)

Significantly elevated levels of lesions $(P<0.001)$ in arsenicrelated Bowen's disease, Bowen's carcinoma and actinic keratosis, compared with their corresponding non-arsenic related conditions (Matsui et al. 1999)

Women who develop breast, or colorectal cancer have elevated levels of serum auto-antibodies to lesions, compared with controls (Frenkel et al. 1998)

Elevated levels of urinary lesions noted in cancer patients before $(P<0.01)$ and after anti-cancer therapy $(P<0.001$; Tagesson et al. 1995)

Lesion significantly elevated $(P \leq 0.05)$ in assorted cancers: fibrillary astrocytoma (brain); lung cancer; mucinous carcinoma (stomach); ovarian cancer; colon cancer (Olinski et al. 1992) 
Table 1. Continued

\begin{tabular}{|c|c|}
\hline Pathological condition & Oxidative DNA lesion levels \\
\hline Cardiovascular disease & $\begin{array}{l}\text { Strong association }(r 0.95, P<0.01) \text { between premature CHD in } \\
\text { men and lymphoctye lesion levels (Collins et al. 1998a) }\end{array}$ \\
\hline $\begin{array}{l}\text { Diabetes mellitus (insulin- and } \\
\text { non-insulin-dependent) }\end{array}$ & $\begin{array}{l}\text { Both groups had significantly higher levels of lesions }(P<0.001) \\
\text { in mononuclear cell DNA compared with controls (Dandona et } \\
\text { al. 1996) }\end{array}$ \\
\hline \multirow[t]{2}{*}{ Diabetes mellitus (non-insulin-dependent) } & $\begin{array}{l}\text { Levels of urinary lesions significantly higher than controls } \\
(P=0.001 \text {; Leinonen et al. 1997) }\end{array}$ \\
\hline & $\begin{array}{l}\text { PBMC levels of oxidised DNA base products significantly ele- } \\
\text { vated in diabetes patients compared with controls (Rehman et } \\
\text { al. 1999b) }\end{array}$ \\
\hline Down's syndrome & $\begin{array}{l}\text { Levels significantly increased }(P=0.00011) \text { in Down's syndrome } \\
\text { subjects compared with controls (Jovanovic et al. 1998) }\end{array}$ \\
\hline \multicolumn{2}{|l|}{ Infection } \\
\hline $\mathrm{HCV}$ & $\begin{array}{l}\text { Leucocyte DNA lesion levels significantly higher than in } \\
\text { HBV infection }(P<0.04) \text {, correlating with clinical diagnosis } \\
(P<0.025) \text { (Farinati et al. 1999) }\end{array}$ \\
\hline \multicolumn{2}{|l|}{ Inflammatory disease } \\
\hline Chronic hepatitis & $\begin{array}{l}\text { Liver levels of lesion significantly elevated }(P<0.05) \text { compared } \\
\text { with controls (Shimoda et al. 1994) }\end{array}$ \\
\hline Cystic fibrosis & $\begin{array}{l}\text { Urinary levels of lesion significantly raised } v \text {. control subjects } \\
\text { (Brown et al. 1995) }\end{array}$ \\
\hline Atopic dermatitis & $\begin{array}{l}\text { Urinary lesion levels significantly higher than in controls } \\
(P<0.0001) \text { and correlating with disease severity index (Tsuboi } \\
\text { et al. 1998) }\end{array}$ \\
\hline Rheumatoid arthritis & $\begin{array}{l}\text { Levels of urinary lesions significantly elevated }(P<0.001) \text { com- } \\
\text { pared with control subjects (Lunec et al. 1994) }\end{array}$ \\
\hline \multirow[t]{2}{*}{ SLE } & $\begin{array}{l}\text { Titres of serum auto-antibodies to lesions significantly elevated } \\
\text { in SLE (Frenkel et al. 1998) }\end{array}$ \\
\hline & $\begin{array}{l}\text { Levels of urinary lesions significantly reduced compared with } \\
\text { control subjects; presence of } 8 \text {-oxodG noted in circulating } \\
\text { immune complexes (Lunec et al. 1994) }\end{array}$ \\
\hline
\end{tabular}

Neurological disease

Parkinson's disease

DNA levels of lesion significantly elevated $(P=0.0002)$ in substantia nigra of Parkinson's disease brains (Alam et al. 1997)

Levels of lesion in cytoplasmic DNA and RNA are elevated in substantia nigra neurons of Parkinson's disease patients and in multiple system atrophy Parkinsonian type and DLB (Zhang et al. 1999)

Alzheimer's disease

Higher levels of lesion in cortex and cerebellum of patients $v$. controls (Lezza et al. 1999)

Ventricular cerebrospinal fluid DNA levels of lesion significantly $(P<0.05)$ elevated compared with controls (Lovell et al. 1999)

DLB

Increased levels of lesions in cortical region of brain in DLB patients compared with control tissue (Lyras et al. 1998)

\footnotetext{
ALL, acute lymphoblastic leukaemia; ORP, oestrogen receptor positive; RCC, renal cell carcinoma; SCC, squamous cell carcinoma; PBMC, peripheral blood mononuclear cell; HCV, hepatitis C virus; HBV, hepatitis B virus; SLE, systemic lupus erythematosus; 8-oxodG, 8-oxo-2'-deoxyguanosine; DLB, dementia with Lewy bodies.
} 


\section{Vitamin C (ascorbic acid)}

Vitamin $\mathrm{C}$ is widely distributed in many fruits and vegetables which serve as the primary source of dietary intake. This water-soluble vitamin may also be taken in as a food preservative. Because of its water solubility vitamin $\mathrm{C}$ readily leaches out of food during cooking. Structurally, vitamin $\mathrm{C}$ is derived from L-gulono- $\gamma$-lactone with the introduction of unsaturation as the last synthetic step (Fig. 1). Vitamin $\mathrm{C}$ can function as a radical scavenger in the aqueous phase, the initial product being the semidehydroascorbyl radical which can be resonancestabilised to diminish reactivity relative to the scavenged species (Bielski \& Richter, 1975). Further one-electron oxidation produces dehydroascorbate which may be reduced back to ascorbate via glutathione or NADH, as may the ascorbyl radical (Halliwell, 1999). Vitamin C may also be involved in the transfer of radical species from lipid to aqueous cellular compartments via regeneration of lipid-soluble membrane-bound antioxidants such as $d$ - $\alpha$-tocopherol. Although vitamin $\mathrm{C}$ has potential antioxidant properties, it has several other important physiological functions in Fe metabolism and as an essential cofactor for enzymic hydroxylation of lysine and proline during collagen synthesis.

\section{Vitamin E (tocopherols and tocotrienols)}

Vitamin E is a term encompassing a group of compounds which exhibit varying degrees of biological activity relative to $d$ - $\alpha$-tocopherol (Brigelius-Flohe and Traber, 1999). The naturally occurring tocopherols with antioxidant activity consist of a group of four tocopherols ( $\alpha-$ to $\delta-$ ) and four tocotrienols ( $\alpha$ - to $\delta$-). Structurally, they consist of a saturated phytyl chain, in the case of the tocopherols attached to a chroman ring, which contains varying numbers and positions of

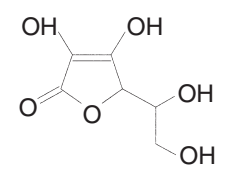

Ascorbic acid

$\mathrm{HO}$

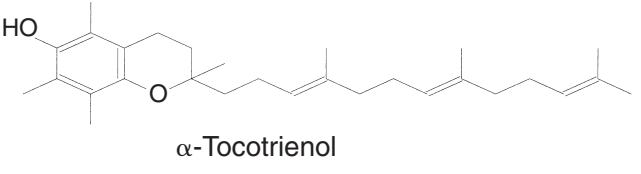

$\alpha$-Tocotrienol

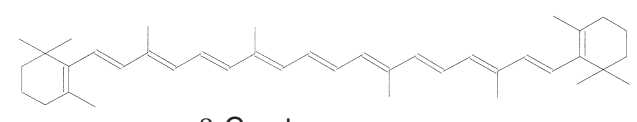

$\beta$-Carotene

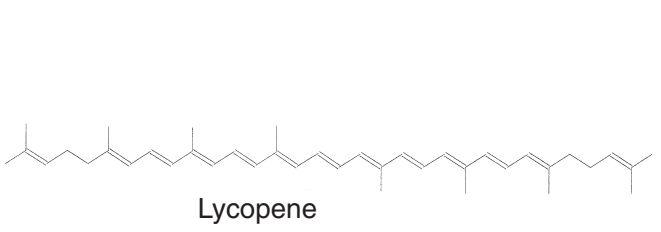

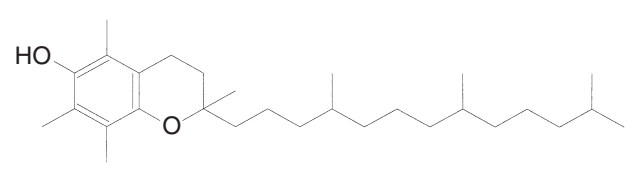

$\alpha$-Tocopherol

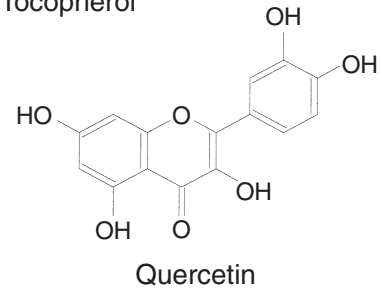

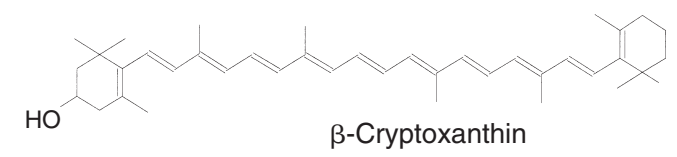

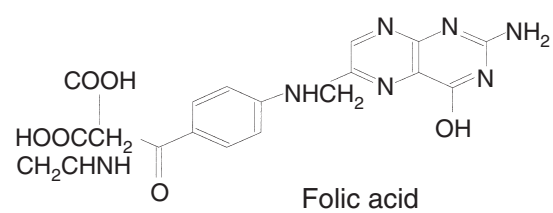

Fig. 1. Representative structures of antioxidant micronutrients. 
methyl substitution. Tocotrienols are similar apart from unsaturation in the phytyl side chain (Fig. 1). The biopotency of these groups of compounds is lower relative to the activity for d- $\alpha$ tocopherol (set at $100 \%$ ) and this includes their antioxidant capacity. The richest, most common sources of vitamin E are vegetable oils (e.g. olive, sunflower, maize and soyabean), products made from them (e.g. margarine, mayonnaise) and whole grains, nuts and seeds. The exact composition of these sources in terms of the individual compounds and the relative intake by different human populations varies. For example, the relatively higher intake of soyabean and maize oils in the American diet accounts for a higher intake of $\gamma$-tocopherol in this population. Intestinal absorption is equivalent for all forms of vitamin E; however passage through the liver results in a distribution such that at least for the tocopherols, $d-\alpha$-tocopherol is preferentially taken up into the bloodstream whereas the other three tocopherols are metabolised and excreted in bile. This selective uptake into the circulation is the result of the hepatic $\alpha$-tocopherol transfer protein (Hosomi et al. 1997). However, $\gamma$-tocopherol is also taken up into the bloodstream but is often present at about 10-fold lower level than $\alpha$-tocopherol, and is rapidly replaced by $\alpha$-tocopherol if this is increased in the diet. Tocopherols would be expected to partition equally into lipid-rich cellular compartments, although studies on preferential sub-cellular distribution patterns are lacking. The antioxidant activity of the tocopherols is expressed in the lipid membrane compartments of cells where it can act as a chain-breaking antioxidant to prevent the propagation of free radical reactions, such as those arising from lipid peroxidation (Kamal-Eldin \& Appelqvist, 1996). The ability of the tocopherols to function effectively as antioxidants is a result of the phenol group. $\mathrm{H}$ abstraction by a peroxyl or $\mathrm{C}$-centred radical, for example, gives a phenoxyl radical, which can be resonance-stabilised and is much less reactive than the lipid-derived radicals and thus poorly available for propagation reactions. Regeneration of tocopherol may occur by redox reaction with ascorbate (vitamin C) or reduced glutathione, thus transferring the radical to the aqueous phase. Although the physiological function of vitamin $\mathrm{E}$ is primarily regarded as an antioxidant, studies are emerging that it may have functions unrelated to its antioxidant activity.

\section{Carotenoids}

Carotenoids comprise a group of compounds closely related in structure that are abundant as plant pigments. Out of 500-600 carotenoids that have been identified, only about six are found in relative abundance in human blood; $\alpha$-carotene (carrots), $\beta$-carotene (orange vegetables and fruits and dark green leafy vegetables), xanthophylls (zeaxanthin, cryptoxanthin and lutein, found predominantly in spinach and kale) and lycopene (tomatoes and tomato products). Structurally, the carotenoids consist of variations on a basic $\mathrm{C}_{40}$ skeleton composed of conjugated double-bonds (Fig. 1); the carotenoid hydrocarbons are composed of the bicyclic carotenes and the acyclic lycopene (Rice-Evans et al. 1997). Xanthophylls are distinguished as O-containing carotenoids (Fig. 1). $\beta$-Carotene is the major precursor of retinol (vitamin A); retinol is found only in foods of animal origin such as liver, dairy products, egg yolks and fish liver oils, as a product of $\beta$-carotene metabolism. These lipid-soluble compounds are absorbed by passive absorption in the small intestine in association with lipid micelles (Parker, 1996). Their lipid solubility means that carotenoids are reduced to basal levels relatively slowly following supplementation, for example. The electron-rich polyene chain of the carotenoids renders them susceptible to electrophilic attack, thereby making them effective free radical scavengers. Carotenoids, because of their lipophilicity are involved in the antioxidant protection of lipid membranes and can act synergistically with tocopherols. They function to inhibit free radical propagation reac- 
tions, such as lipid peroxidation, in a similar manner to tocopherols. The resultant carotenoidfree radical is stabilised and therefore rendered less reactive by delocalisation of the free electron over the conjugated double bond system. The extensive conjugated double bond system is also responsible for the effective ${ }^{1} \mathrm{O}_{2}$ scavenging abilities of carotenoids.

\section{Phytochemicals}

Among phytochemicals we include a range of compounds that have more recently become thought of as important in modulating oxidative stress. As the name implies these are compounds derived from plant material and they are not classified amongst the groupings outlined above. However, an appreciation of their potential importance is growing as many representatives of this group of compounds have demonstrated antioxidant function and are being studied in human subjects. There are multiple dietary sources of these compounds as they are present in virtually all plant material. Flavonoids are ubiquitously distributed in vascular plants and comprise a group of over 2000 compounds. The richest dietary sources for these compounds are fruits, vegetables, coffee, tea, cocoa and alcoholic beverages. These compounds are also termed polyphenols and are grouped under flavones (e.g. chrysin; fruit skin), flavanols (e.g. catechin, epicatechin, epigallocatechin; green and black teas, wine), flavonones (e.g. naringin and taxifolin; citrus fruits), flavonols (e.g. quercetin; many fruits and vegetables), methylated flavones and $O$-glycoside derivates of the flavonoids which are the most abundant form of these compounds (Hollman \& Katan, 1999). Formation of the free polyphenol by glycosylase activity in the gastrointestinal tract, for example, is necessary to confer antioxidant function. Structurally the flavonoids all have the basic structure of the diphenylpropane skeleton $\left(\mathrm{C}_{6} \mathrm{C}_{3} \mathrm{C}_{6}\right)$ substituted with differing numbers and arrangements of hydroxyl groups to produce the individual members (Rice-Evans et al. 1996). The phenolic groups serve as a source of readily available $\mathrm{H}$ atoms such that the subsequent radical produced can be delocalised over the flavonoid structure. More simple phenolic compounds, as with the flavonoids, are found mostly as the $O$-glycoside derivatives and are widely distributed in plants; examples include caffeic and ferulic acids. Again it is the phenolic moieties that confer the ability of these compounds to act as effective radical scavengers, in conjunction with the ability of the electron to become delocalised across the structure. Phyto-oestrogens, including isoflavonoids are also polyphenolic compounds but possess weak oestrogenic activity exerted through the oestrogen receptor. Their protective effects in cells lacking oestrogen receptors suggests they possess other functions, such as antioxidant activity imparted by their polyphenolic nature. Allium compounds derived from garlic, onions and chives are S-containing compounds that are in part responsible for the distinctive taste and odour properties of these vegetables. There are several unique water- and lipid-soluble organosulfur compounds with antioxidant properties in these vegetables, e.g. allixin and allicin (from garlic, this is converted to more bioavailable water-soluble organosulfur compounds, S-allylcysteine and S-allylmercaptocysteine upon ageing of crushed garlic). Allium compounds can exert antioxidant function by direct scavenging of ROS in addition to enhancing antioxidant enzymes such as catalase, superoxide dismutase, glutathione peroxidase and glutathione (Borek, 2001).

\section{Folic acid}

Although folic acid is not traditionally recognised as an antioxidant nutrient, recent evidence indicates that this compound is an effective free radical scavenger and thus its role may extend beyond that of its critical function in one-C metabolism, specifically methylation processes (Joshi 
et al. 2001). The major dietary sources of folic acid are dark leafy vegetables and wholegrain cereals. The parent molecule, folic acid (pteroyl glutamic acid), forms the structural basis for multiple derivatives involved in one- $\mathrm{C}$ metabolism, dihydrofolic acid, tetrahydrofolate, 5-methyltetrahdrofolate and 10-formyltetrahydrofolate. These compounds are then involved in the synthesis of thymidine for example, and it is this function which impacts directly on DNA stability.

\section{Epidemiological evidence for the possible protective effects of dietary antioxidants}

Given the postulated significant role for free radical species in disease, many epidemiological studies have examined the relationship between serum and plasma antioxidant levels and cancer incidence (results summarised in Table 2). Whilst these results support the protective effect of a diet rich in fruit and vegetables, the role of individual antioxidants would appear to be very much more under question (for reviews, see Byers \& Perry, 1992). Nevertheless, the explanation for how antioxidant micronutrients may have a protective effect against cancer is plausible, although failure of epidemiological studies to support this has led to focus upon the effects of supplementation on in vivo oxidative DNA damage.

\section{Experimental evidence for the protective effects of antioxidants}

The data relating to the possible protective effects of dietary antioxidants can be simply divided into two groups; the first group of studies examines diets rich in antioxidant-containing vegetables; the second relates to supplementation with specific antioxidants. The latter group contains by far the larger number of studies.

Table 2. Potential for high dietary antioxidant levels to affect the risk of cancer development at specific sites*

\begin{tabular}{|c|c|c|c|c|}
\hline \multirow[b]{2}{*}{ Cancer site } & \multicolumn{4}{|c|}{ Nutritional antioxidant } \\
\hline & Vitamin C & Vitamin $\mathrm{E}$ & Carotenoids & Vegetables and fruit \\
\hline Bladder & Insufficient & & Insufficient & Probable \\
\hline Breast & Insufficient & & Possible & Probable \\
\hline Cervix & Possible & Possible & Possible & Possible \\
\hline Colon, rectum & Insufficient & Insufficient & Possible & Convincing (for vegetables) \\
\hline Endometrium & & & Insufficient & Possible \\
\hline Kidney & & & & Possible \\
\hline Larynx & Insufficient & & Insufficient & Probable \\
\hline Liver & & & & Possible (for vegetables) \\
\hline Lung & Possible & Possible & Probable & Convincing \\
\hline Mouth and pharynx & Possible & & & Convincing \\
\hline Oesophagus & Possible & & Possible & Convincing \\
\hline Ovary & & & Insufficient & Possible \\
\hline Pancreas & Possible & & & Probable \\
\hline Prostate & & & & Possible \\
\hline Stomach & Probable & & Possible & Convincing \\
\hline Thyroid & & & & Possible \\
\hline
\end{tabular}

* Data derived from World Cancer Research Fund/American Institute for Cancer Research (1997). Judgements are graded according to the strength of the evidence derived from case-control ( $\geq 200$ cases) and cohort ( $\geq 100$ cases) studies. Definitions: convincing, conclusive evidence for a causal relationship; probable, evidence strong enough to conclude a likely causal relationship; possible, a causal relationship may exist; insufficient, suggestive evidence exists but there is too little or it is imbalanced. 


\section{Vitamin E (tocopherols and tocotrienols)}

The cancer preventative ability of vitamin E would appear to be least investigated (Table 2), perhaps because most of the studies examining the protective effects of vitamin $E$ have focused upon cardiovascular disease. Indeed, only limited studies have examined the effects of vitamin E upon oxidative DNA damage in vivo (Claycombe \& Meydani, 2001). Of these studies, three, supplementing with 200, 400, 500, or $800 \mathrm{IU} / \mathrm{d}$ failed to show any effect upon urinary 8-oxodG (Priemé et al. 1997), lymphocyte single strand breaks (Astley et al. 1999) or lymphocyte micronuclei frequency (Fenech et al. 1997), respectively. Equally, a liquid formula diet, described as nutritionally complete and fortified with high vitamin $\mathrm{E}$ and polyunsaturated fatty acids did not lower leucocyte 8 -oxodG levels, although a significant $(P=0 \cdot 04)$ downward trend was noted (Chen et al. 1999). In contrast, only two studies reported a significant decrease in DNA strand breaks; $80 \mathrm{IU} / \mathrm{d}$ in conjunction with a $5 \%$ polyunsaturated fatty acid diet; $P=0.01$ (Jenkinson et al. 1999) and $280 \mathrm{IU} / \mathrm{d} ; P<0.002$ (Duthie et al. 1996). In the case of the latter study, however, a cocktail of antioxidant nutrients was used $(100 \mathrm{mg}$ vitamin $\mathrm{C} / \mathrm{d}$ and $25 \mathrm{mg} \beta$ carotene/d in addition to vitamin E) and thus a DNA protective effect cannot be ascribed to vitamin E alone. A third study, supplementing volunteers with $400 \mathrm{IU} / \mathrm{d}$, showed a decrease in peripheral blood mononuclear cell (PBMC) levels of 8-oxodG, as measured by HPLC-EC, although no change in 8-oxodG or 8-oxodA was seen, in the same cells, measured by GC-MS (Lunec et al. 1999). The authors attributed this lack of agreement between the two methods to superior sensitivity and reproducibility of the HPLC-EC (Lunec et al. 1999). Testing the hypothesis for a relationship between dietary antioxidants in a typically Mediterranean diet and oxidative DNA damage did not show any correlation between vitamin E levels and lymphocyte levels of 8-oxodG, as measured by HPLC-EC (Bianchini et al. 2000). Nor were plasma vitamin E levels significantly higher in the Mediterranean diet compared with a population in Sweden (Bianchini et al. 2000). Indeed, contrary to the expected findings, lymphocyte 8-oxodG levels were significantly higher $(P<0.01)$ in the Mediterranean group compared with the Swedish group (see also for carotenoids, below).

\section{Carotenoids}

Studies suggest that the DNA protective effect of carotenoids is concentration-dependent and protection has been noted in vitro using physiological concentrations, i.e. those detected in plasma of individuals consuming healthy diets without supplementation (Lowe et al. 1999). At levels that may be achieved when using supplements, carotenoids may increase DNA damage; this phenomenon has been put forward as one explanation for the increased incidence of lung cancer in smokers seen on recent carotenoid supplementation studies (Alpha tocopherol, $\beta$ carotene Cancer Prevention Study Group, 1994; Omenn et al. 1996). Although a common feature of these two supplementation studies was that smokers were used, it has also been suggested that carotenoids may increase xenobiotic metabolism through cytochrome P-450 induction, perhaps facilitating metabolic activation of smoke-borne carcinogens (Murata \& Kawanishi, 2000). Factors such as the $\mathrm{O}$ tension and the identity of the oxidising species may also determine whether carotenoids are protective or not under certain conditions (Woods et al. 1999; Yeh \& Hu, 2000; Zhang \& Omaye, 2001).

Studies examining the relationship between plasma carotenoid levels, oxidative DNA damage in peripheral blood lymphocytes (PBL), and the resistance to exogenous oxidative insult of PBL, have been reported. Many of these studies have involved either supplementation regimens with single carotenoids or the use of carotenoid-rich, 'functional', foods. In the case of the lat- 
ter, to ascribe any protective effect to carotenoids alone some measurement of blood levels of carotenoids and correlations with levels of DNA damage need to be performed, since several other plant-derived antioxidants such as flavonoids could be responsible for any observed protective effect. The various supplementation or dietary manipulation studies performed in human subjects to address the antioxidative effects of carotenoids on oxidative DNA damage show a predominant protective effect. Significant negative correlations were detected between total serum carotenoid levels and oxidised pyrimidine levels in PBL DNA, from subjects supplemented with $\alpha$ - or $\beta$-carotene, lutein or lycopene, measured using a modified Comet assay (Collins et al. 1998b). In a similar study subjects given lycopene, lutein or $\beta$-carotene (15 mg/d for 1 week) showed 2- to 3-fold increases in plasma carotenoid concentration, which reverted to basal levels after a 3-week wash-out period. An increased resistance of PBL isolated from the supplemented subjects to hydrogen peroxide-induced DNA strand breakage as measured by the Comet assay was observed (Torbergsen \& Collins, 2000). A lowering of baseline levels of 24-h urinary 8-oxodG was detected in eight healthy non-smoking male subjects supplemented with $30 \mathrm{mg} \beta$-carotene/d for 1 month, which increased plasma $\beta$-carotene levels 17 -fold compared with a placebo group (Sumida et al. 1997). In terms of dietary manipulation studies or intervention with functional foods, the antioxidant effects of carotenoids have been similarly encouraging. Twenty-eight healthy female subjects participated in a 14-d recipe-defined diet rich in fruit and vegetables (Thompson et al. 1999). Post-intervention plasma carotenoid levels increased relative to pre-intervention levels but to differing extents, with $\alpha$-carotene levels increasing most markedly out of those measured. Overall, fruit and vegetable consumption showed a trend towards reduction in levels of PBL and urinary 8-oxodG, although this was not statistically significant. Plasma $\alpha$-carotene levels did correlate significantly with a reduction in PBL 8-oxodG, at least for individuals with inherently low pre-supplementation levels of $\alpha$-carotene $(<98$ $\mathrm{ng} / \mathrm{ml}$ ). Those subjects with higher pre-supplementation levels of $\alpha$-carotene showed a reduction in PBL 8-oxodG, although this was not statistically significant. Whilst there was a trend toward reduction in urinary levels of 8-oxodG in both groups this was also not statistically significant. These data would suggest that individuals with higher levels of carotenoids may maintain inherently lower levels of oxidative DNA damage. Strong inverse correlations between plasma carotenoids (lutein, $\beta$-cryptoxanthin) and markers of oxidative DNA damage (urinary and PBL DNA levels of 8-oxodG measured by ELISA and HPLC-EC respectively) were detected in thirty-seven female subjects participating in a 14-d dietary intervention study equivalent to twelve servings of fruit and vegetables/d (Haegele et al. 2000). Damage to DNA, measured by the Comet assay, as strand breaks or oxidised pyrimidines, was examined in PBL from twenty-three healthy, non-smoking male subjects who initially abstained from a carotenoid-rich diet for 2 weeks before receiving either tomato juice (lycopene), carrot juice ( $\alpha$ - and $\beta$ carotene) or dried spinach powder (lutein). All three dietary regimens induced a decrease in DNA strand breaks with carrot juice specifically decreasing oxidised pyrimidine levels (PoolZobel et al. 1997). Again, using the Comet assay, a highly significant decrease in PBL DNA damage was detected in twenty-eight healthy elderly volunteers (mean age 68 years) given a fruit and vegetable extract juice twice daily for $80 \mathrm{~d}$ (Smith et al. 1999).

Processed tomato products, such as tomato juice or tomato puree, are a significant source of lycopene and in some cases this carotenoid in particular has been the focus of attention. Significant increases in plasma and/or PBL lycopene levels were noted in two studies where adult females consumed tomato puree $(25 \mathrm{~g} / \mathrm{d}$ for $14 \mathrm{~d})$ as part of a dietary manipulation study (Riso et al. 1999; Porrini \& Riso, 2000). Resistance of PBL to DNA damage following hydrogen peroxide challenge in these subjects was increased, as assessed by the Comet assay, with an inverse relationship between lycopene concentration and DNA damage. Using GC-MS to mon- 
itor oxidised base lesions in PBL, Rehman et al. (1999a) showed that a single serving of tomatoes in healthy human subjects was sufficient to decrease the level of some oxidative DNA lesions (8-oxo-guanine), yet the levels of other lesions (8-oxo-adenine) were increased. This trend is the same as that described by Podmore et al. (1998a) in a widely reported vitamin C supplementation study. Subsequent studies have implied that this divergent trend for two oxidative lesions may be explained by a modulation of DNA repair activities for one lesion over another. Although evidence for this sort of function from vitamin $\mathrm{C}$ is emerging, this apparent effect for carotenoids has been questioned (Torbergsen \& Collins, 2000). Since all oxidative DNA lesions do not behave in the same way, but change in a divergent manner in such supplementation studies, this would question the idea that carotenoids merely act as antioxidants rather than modulating DNA repair in PBL. As discussed in the next section (pp. 30-31), vitamin $\mathrm{C}$ may modulate DNA repair by providing a priming oxidative stimulus. Such an oxidative priming phenomenon for carotenoids would not be an unreasonable route to modulate DNA repair, since pro-oxidant properties for carotenoids have been noted in some studies.

The majority of dietary intervention studies indicate that a carotenoid-rich diet reduces the levels of oxidative DNA damage, although there are studies that show a positive correlation of plasma carotenoid levels with markers such as PBL 8-oxodG level. Such a study was reported recently by Bianchini et al. (2000) using subjects from Northern and Southern Europe. While this study may indicate that high plasma carotenoids are inducing or leading to a persistence of oxidative DNA damage, the authors admit that there may be other dietary components of the population being studied that are promoting oxidative DNA damage. A 12-week carotene supplementation regimen (palm oil carotenes ( $\alpha$ - and $\beta$-carotene), lycopene and lutein) along with a placebo group was conducted in five European countries. Not all samples were analysed for the same parameters, but in those instances where pre- and post-supplementation assessments of serum carotenoids and PBL DNA levels of 8-oxodG were assessed, levels of carotenoids increased significantly on supplementation but 8-oxodG levels were unaffected. One feature of this supplementation study was that there was a 4-week vitamin E supplementation phase immediately preceding the carotenoid supplementation (Collins et al. 1998a). What may be apparent is a complex interplay between individual carotenoids and probably other food components to determine any overall in vivo antioxidative effect. An intake of these species in a complex food matrix may be more useful to study and of more benefit to the population than the promotion of individual nutrient supplements.

\section{Phytochemicals}

Studies of the protective effects of flavonoids, phyto-oestrogens and the other phytochemicals detailed earlier (see p. 26) on oxidative DNA damage in vivo in human subjects are relatively limited at present. Most of the studies to date have focused on in vitro experiments using cells pretreated with the compound of interest before exposure to an oxidative stress and also studies using rodents fed phytochemical-rich diets (Duthie et al. 1997; Noroozi et al. 1998; Casalini et al. 1999; Aherne \& O'Brien, 2000; Johnson \& Loo, 2000). Studies of the DNA protective effects of dietary flavonoids in vivo are required since extrapolation of in vitro data is probably an oversimplification. Since these compounds are ubiquitous in plant species there could be any number of compounds involved in DNA protective effects. As with the carotenoid studies, measurements of blood levels of the compounds of interest should be made and correlations drawn between these levels and any modulation of DNA damage. Only in recent years have studies moved beyond the in vitro and rodent studies and on to dietary supplementation with flavonoid rich foods. Findings from these 
studies, when taken together are still equivocal, in part because insufficient studies have been performed addressing one compound or a group of related compounds. A recent study in thirty-six healthy human subjects assessed the impact of a high-flavonol diet (onion cake and black tea; primarily quercetin) on a number of factors in particular oxidative DNA damage in PBL (Beatty et al. 2000). The high-flavonol dietary regimen significantly increased plasma quercetin levels, but no significant decrease in oxidative DNA damage products in PBL was detected by GC-MS. Significant elevation of plasma flavonoids (quercetin, kaempferol and isorhamnetin) was observed in a group of eighteen healthy female volunteers receiving rutin (quercetin-3-O-beta-rutinoside) supplements $(500 \mathrm{mg} / \mathrm{d}$ for 6 weeks). No significant change in urinary 8-oxodG levels was noted in either the rutin- or placebo-supplemented groups whilst both groups showed significant decreases in oxidised pyrimidine levels as measured by the Comet assay using endonuclease III (Boyle et al. $2000 a$ ). Although the nature of the compounds investigated was slightly different, a study using volunteers fed rye crispbread $(76.5 \mathrm{~g} / \mathrm{d} ; 42 \mu \mathrm{g}$ secoisolariciresinol and $33 \mu \mathrm{g}$ matairesinol/100 $\mathrm{g}$ dry weight) found little evidence to indicate that isoflavonoids or lignin would exert a significant antioxidative effect systemically. In this case oxidised purine and pyrimidine lesions were assessed in PBL DNA using a modified Comet assay (Pool-Zobel et al. 2000). This lack of DNA protection could in part be due to the fact that adequate concentrations of these compounds are not achieved physiologically. Whereas these compounds may have a significant protective effect in an in vitro study, these findings again emphasise the need for controlled in vivo studies in human subjects.

There are some studies that show an apparent DNA protective effect of dietary flavonoids. A dietary regimen consisting of fried onions or fried onions plus fresh cherry tomatoes was used to study the effects of flavonoids on markers of oxidative damage to biomolecules, including DNA (Boyle et al. 2000b). Plasma flavonoid glycosides were significantly increased following the fried onion meal and this increase was associated with an increased resistance of PBL to oxidant-induced DNA strand breakage and a decrease in urinary 8-oxodG, $4 \mathrm{~h}$ after the meal. The decrease in urinary 8-oxodG is taken to reflect a decrease in oxidative DNA damage. Quercetin alone was increased in plasma following the onion and tomato meal, with a reduction in endogenous oxidative DNA damage but an unchanged resistance to strand breakage. The dietary manipulation using onion meals does not apparently take into account the protective roles of allium compounds, for example. Ten patients with stable type II diabetes were treated for 2 weeks on a low flavonol and then for 2 weeks on a flavonol-supplemented diet (approximately $100 \mathrm{mg}$ flavonols, predominantly quercetin, provided as $400 \mathrm{~g}$ onion and tomato sauce and six cups of tea). Plasma flavonol concentrations increased 12-fold on the flavonol-supplemented diet. DNA damage in PBL from the patients was assessed using the Comet assay and was significantly decreased when taking the flavonol-supplemented diet (Lean et al. 1999).

Finally, a supplementation study using soya milk (a rich source of phyto-oestrogens) in ten healthy male volunteers gave significant increases in plasma levels of the phyto-oestrogens genistein and daidzein, and to a significant reduction in oxidative DNA damage in PBL using the Comet assay (Michell \& Collins, 1999). The antioxidant effects of phyto-oestrogens may go beyond their inherent potential to scavenge free radical species, since they could also modulate the activity of antioxidant enzymes (Cai \& Wei, 1996); this aspect of DNA protection by antioxidants is considered in more detail in the next section.

\section{Vitamin C}

From the epidemiological studies summarised in Table 2, it would appear that the cancerpreventing ability of vitamin $\mathrm{C}$ remains questionable. The contentious nature of this subject 
perhaps derives, in part, from the in vitro studies, summarised in a recent review (Carr \& Frei, 1999) which appeared to show that there is as much evidence for a pro-oxidant effect upon DNA damage, as antioxidant. This would also seem to hold true for some of the in vivo studies.

Perhaps the first evidence for a protective effect in vivo derived from the seminal work by the group of Bruce Ames in which the vitamin C levels of ten volunteers were depleted and repleted (Fraga et al. 1991). This work demonstrated that decreasing vitamin C intake from 250 $\mathrm{mg} / \mathrm{d}$ to $5 \mathrm{mg} / \mathrm{d}$, led to a doubling of sperm DNA levels of 8-oxodG (34.0 (SD 2.4) fmol/ $\mu \mathrm{g}$ DNA to 66.90 (SD $8.5 \mathrm{fmol} / \mu \mathrm{g}$ DNA; $P<0.01$ ), although continued depletion resulted in a 248 $\%$ increase (Fraga et al. 1991). Repletion at $250 \mathrm{mg} / \mathrm{d}$ for $28 \mathrm{~d}$ led only to a $36 \%$ decrease in 8 oxodG levels. An identical study, by the same group, also showed an increase in sperm levels of 8-oxodG, although depletion had no effect on either urinary 8-oxodG or the 8-oxodG content of PBMC (Jacob et al. 1991).

Urinary 8-oxodG in 24-h urine collections was the sole DNA damage marker measured by ELISA during a supplementation study with $500 \mathrm{mg}$ vitamin $\mathrm{C} / \mathrm{d}$ for 2 months (Huang et al. 2000). At baseline, dietary intakes of vitamin $C$ were inversely associated, although not significantly, with urinary 8-oxodG (17.6 (SD 10.4) ng/mg creatinine); upon supplementation no decrease in urinary 8-oxodG was noted, either with vitamin C alone (19.3 (SD 9.3) ng/mg creatinine), or in combination with vitamin E (17.7 (SD 9.5) $\mathrm{ng} / \mathrm{mg}$ creatinine). The authors suggested that the lack of significance may be due to the 2-month study period being too short, and this issue is discussed later (p. 35). Similarly, urinary levels of 8-oxoguanosine (the damaged RNA product) did not alter from baseline (about 400 (SD 50) pmole 8-oxoguanosine/kg per d) following supplementation with $1 \mathrm{~g}$ vitamin C/d for 1 month (Witt et al. 1992). In contrast to measuring lesion levels in PBMC following in vivo supplementation, PBMC may be challenged ex vivo by hydrogen peroxide before assessment, by cytokinesis-block micronucleus assay, Comet assay (DNA strand break measurement) and chomosomal aberrations, for example. Using the former approach, Crott \& Fenech (1999) reported no apparent DNA damage following a single $2 \mathrm{~g}$ bolus of vitamin $\mathrm{C}$. Although equally, there was no protection of the PBMC against hydrogen peroxide toxicity. Even doses as large as $6 \mathrm{~g}$ vitamin $\mathrm{C} / \mathrm{d}$ failed to show any beneficial effects, as assessed by DNA strand break measurement using the Comet assay, following hydrogen peroxide challenge in non-smoking individuals with 'low' and 'high' cholesterol (Anderson et al. 1997).

A number of studies have shown that larger increases in plasma vitamin $\mathrm{C}$ levels are seen following supplementation of individuals with low initial levels (Calzada et al. 1997; Rehman et al. 1998). Indeed, initial ascorbate status may also affect 8-oxodG levels (Rehman et al. 1998) and a number of studies have compared intrinsic vitamin C levels with oxidative DNA damage. A negative correlation was demonstrated between intracellular ascorbate and lymphocyte DNA levels of 8-oxodG $(r-0.28 ; P<0 \cdot 01)$ and 5-OH-deoxycytidine $(r-0 \cdot 07 ; P<0 \cdot 01)$, from a study of 105 healthy volunteers (Lenton et al. 1999), although no such correlation was seen with urinary 8-oxodG, in a similar study by Poulsen et al. (1998).

Vitamin $\mathrm{C}$ is commonly used to enhance peroxidative processes involving transition metal ions and has been suggested to generate radicals from the decomposition of lipid hydroperoxides (Baysal et al. 1989). However, whilst the point has been made that such a pro-oxidant activity does not occur in healthy human plasma, containing low levels of lipid hydroperoxides and no detectable metal ions (Stocker \& Frei, 1991), this argument may not be simply applied to the environment surrounding DNA. Furthermore, pathological conditions do exist where lipid hydroperoxide or metal ions may conceivably be elevated and therefore vitamin supplementation may very well exert a pro-oxidant effect. Indeed, a number of supplementation stud- 
ies in healthy volunteers with vitamin $\mathrm{C}$ alone or in combination with Fe have shown an increase in some oxidative DNA lesions, although with a concomitant antioxidant effect (Podmore et al. 1998a; Rehman et al. 1998). However, upon repeating the study of Rehman et al. (1998; $260 \mathrm{mg}$ vitamin C/d and $14 \mathrm{mg} \mathrm{Fe} / \mathrm{d}$ ), no overall change in the 'total' oxidative DNA damage was noted, despite some lesion levels increasing and some decreasing (Proteggente $e t$ al. 2000).

Vitamin C supplemented at a level of $500 \mathrm{mg} / \mathrm{d}$ for 6 weeks significantly increased plasma vitamin $\mathrm{C}$ levels in healthy volunteers and was shown to increase levels of 8-oxodA, whilst at the same time lowering levels of 8-oxodG in PBMC DNA (Podmore et al. 1998a). As the lesions acted in a completely divergent manner in response to vitamin $\mathrm{C}$, this phenomenon, contrary to many criticisms levelled at the work, could not be due to artifact and demonstrated an apparent pro-oxidant effect (Podmore et al. 1998b). A study extending supplementation to doses of 500, 1000 and $5000 \mathrm{mg}$ vitamin C/d failed to demonstrate a pro-oxidant effect at any dose (Vojdani et al. 2000). Explanation for this finding may derive from the authors measuring 8-oxodG in leucocyte DNA which decreased in the study of Podmore et al. (1998a), whereas 8oxodA increased. Equally, no decrease in 8-oxodG and hence antioxidant activity was noted (Vojdani et al. 2000).

A compelling hypothesis explaining these results derived from the analysis of serum and urinary levels of 8-oxodG in the same subjects (Cooke et al. 1998). The sequential decrease in PBMC DNA levels of 8-oxodG and increase in serum and urinary 8-oxodG levels suggested that, rather than a purely radical-scavenging antioxidant effect, vitamin $\mathrm{C}$ was influencing DNA repair enzymes (Cooke et al. 1998). Similar, albeit non-significant, increases in urinary 8oxodG were noted during vitamin C supplementation (Priemé et al. 1997) or high fruit and vegetable diet (Hertog et al. 1997). This lack of significance during supplementation is consistent with the findings of Cooke et al. (1998) and led to the suggestion of a post-supplementation effect of vitamin C. This effect is exemplified by a recent result with $400 \mathrm{mg} / \mathrm{d}$ supplementation for 10-20 weeks (Carty et al. (2000); Fig. 2). A pro-oxidant effect was seen initially, with PBMC DNA levels of 8-oxodG, as measured by HPLC-EC, rising significantly $(P=0.05) 28 \%$ before a highly significant $(P=0.001)$ reduction of $60 \%$ which was maintained even after the volunteers were split into two groups, with one taking placebo (Fig. 2). The same study also demonstrated a dose effect upon urinary oxidative DNA damage markers, with a transient, significant increase in urinary 8-oxodG levels $(P=0.05)$ and only when compared with baseline, rather than placebo (MS Cooke, N Mistry, J Ahmad and J Lunec, unpublished results). Furthermore, the initial pro-oxidant phase seen is consistent with the $500 \mathrm{mg} / \mathrm{d}$ study of Podmore et al. (1998a), despite only being seen in 8-oxodA, but nevertheless agrees with the suggestion that this effect primes DNA repair (Lunec et al. 2000a).

The potential role of vitamin $\mathrm{C}$ in DNA repair was further elucidated in a study of deoxycytidine-glyoxal adduct (dC-glyoxal), an oxidative DNA lesion, and thymine dimer $(\mathrm{T}<>\mathrm{T})$, a non-oxidative, u.v.-derived lesion, removal from PBMC DNA, following supplementation with 400 mg/d (N Mistry, ID Podmore, MS Cooke, J Ahmad, L Dickinson, Jones GDD, HR Griffiths, KE Herbert and J Lunec, unpublished results). The authors noted an initial increase in dC-glyoxal levels, which was not seen in the $\mathrm{T}<>\mathrm{T}$, proposed to derive from an initial pro-oxidant effect, followed by a subsequent reduction in both $\mathrm{dC}$-glyoxal and $\mathrm{T}<>\mathrm{T}$, implying their removal by the same, or similar repair processes. Given that the removal of $\mathrm{T}<>\mathrm{T}$, which is exclusively repaired, in man, by nucleotide excision repair, coincides with the removal of $\mathrm{dC}$ glyoxal, the authors propose that cytosine-glyoxal adducts are repaired by nucleotide excision repair pathways and it is these which are influenced by vitamin $\mathrm{C}$ supplementation. 


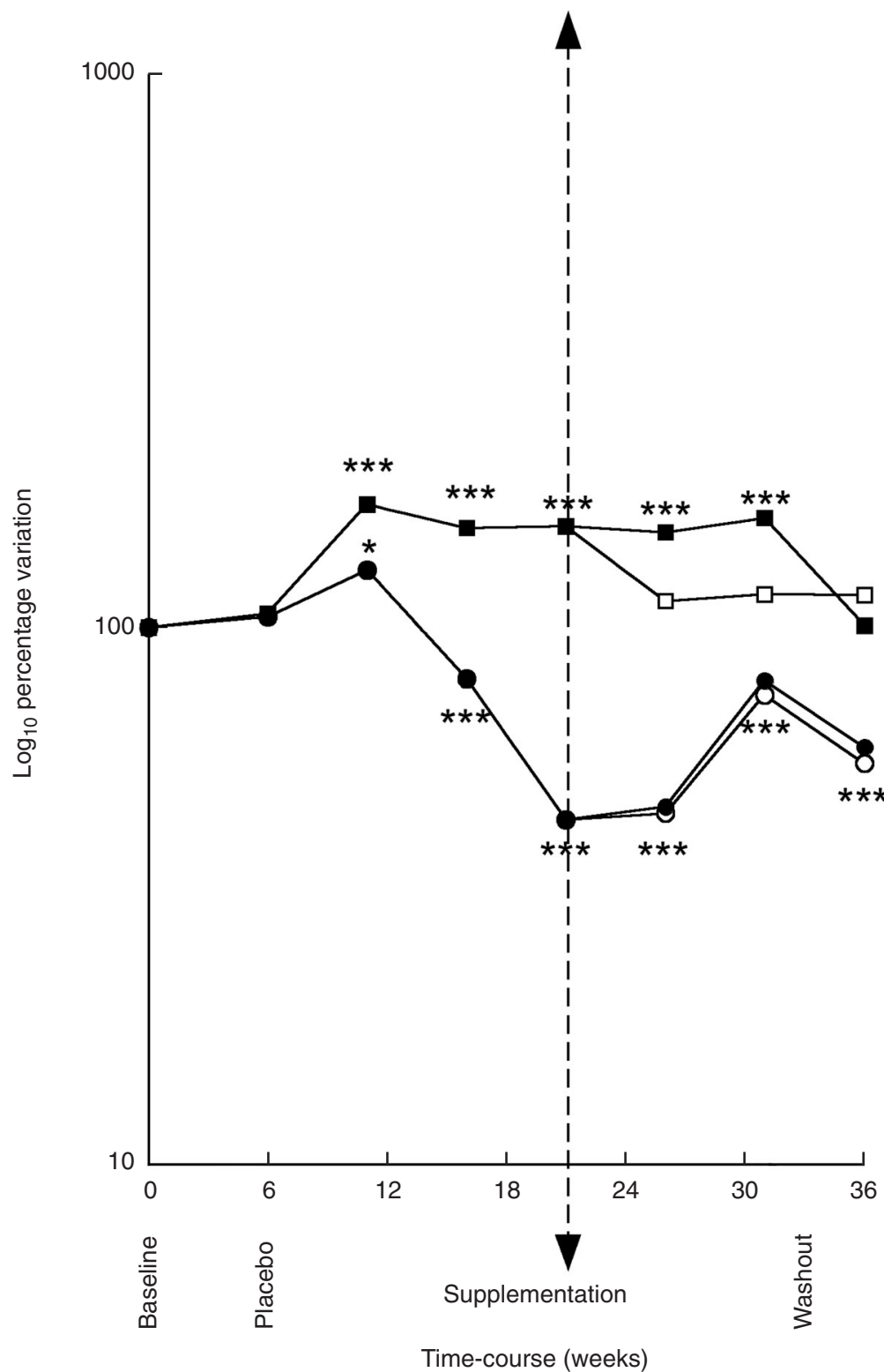

Fig. 2. Representation of 8-oxo-2'-deoxyguanosine levels in peripheral blood mononuclear cell DNA, assessed by HPLC-electrochemical detection, in healthy volunteers following supplementation with $400 \mathrm{mg}$ vitamin $\mathrm{C} / \mathrm{d}(\mathbf{O})$ or placebo $(\bigcirc)$ and comparison with plasma vitamin $C$ levels in the supplemented $(\square)$ and placebo $(\square)$ groups. At the point indicated $\left(\begin{array}{l}\mathbf{i} \\ )\end{array}\right)$ the group was split and double-blind, randomly-assigned to either remain on vitamin $C$ or change to placebo (calcium carbonate). The trial format is described fully in Carty et al. (2000). Data are expressed in terms of mean percentage variation from baseline $(100 \%)$. Variation was significantly different from baseline and placebo measurements: ${ }^{\star} P=0.05,{ }^{\star \star \star} P=0.001$. 


\section{Folic acid}

A role for a direct antioxidant function of folic acid in vivo and indeed in vitro is currently extremely limited and presents novel avenues for study. However, the function of folic acid and derivates in methylation reactions indicates that a deficiency of this vitamin can adversely affect DNA synthesis and repair, by impacting on thymidine synthesis. Folate deficiency induces an increase in uracil mis-incorporation into DNA, and an overall decrease in DNA stability, by increasing the frequency of DNA strand breaks (Duthie et al. 2000). Some studies, although not in human subjects, indicate that base excision repair is specifically affected by folate deficiency (Choi et al. 1998; Duthie \& Hawdon, 1998). Because folate deficiency can diminish the repair of DNA damage, including oxidative DNA damage, then its deficiency would increase the impact of such damage on DNA integrity by uracil mis-incorporation into DNA during post-excision DNA synthesis. Folic acid would not therefore appear to impact directly on the formation or removal of oxidative DNA damage, but may enhance the genotoxicity of oxidised DNA by an impairment of DNA repair processes. Significant uracil incorporation into DNA would result in removal by uracil DNA glycosylase and the introduction of nicks. Should nicks also arise on opposite strands, this could lead to double-strand break formation.

\section{Intervention study considerations}

Whilst the following points relate to vitamin $\mathrm{C}$ supplementation specifically, there is no reason why these considerations may not be applied to the study of other antioxidants.

Demonstrating evidence for an anti- or even a pro-oxidant effect for vitamin $\mathrm{C}$ in vivo would seem to depend on a number of factors:

Dose. There is evidence for a dose effect; urinary levels of 8-oxodG following $400 \mathrm{mg}$ vitamin C/d (see p. 33) did not rise to the same level of significance as the previous study (Cooke et al. 1998). A dosing study, comprising the measurement of more than one oxidative lesion and in a number of biological matrices, would seem to be essential.

Duration of supplementation. Supplementation studies comprising a few weeks to a couple of months may not fully represent the effects seen with long-term antioxidant intake. Even so, supplementation with $500 \mathrm{mg}$ slow release vitamin $\mathrm{C} / \mathrm{d}$ (and/or $128 \mathrm{mg}$ vitamin E) over a period of 36 months failed to show any effects upon urinary 8-oxodG, when sampled at 12 and 36 months (Porkkala-Sarataho et al. 2000), although this might be explained by when sampling is taken.

When sampling is taken. Any effect may be transient and the correct timepoint might be missed, or sampling may not continue for long enough and miss any post-cessation effect (see vitamin C, p. 33).

Lesion(s) measured. Certainly the work of Rehman et al. (1998) and Proteggente et al. (2000), due to the large number of lesions measured, illustrates how supplementation may have a prooxidant effect on some lesions and an antioxidant effect on others. However, the problem with defining effect based on 'total' oxidative DNA damage changes is that every single oxidative DNA lesion, and presumably this would include ribose damage and backbone modification, would need to be measured, not just the lesions that have been identified and can be measured. 
Which tissue to sample. In which tissues or biological matrices, such as serum and urine, is it important to assay for oxidative DNA damage? Clearly this can affect the results; for example, Jacob et al. (1991) showed that upon depletion of plasma vitamin C in volunteers, sperm levels of 8-oxodG went up, but no effect was seen in PBMC 8-oxodG or urinary 8-oxodG. PBMC are often used as surrogate cells, to provide information relating to tissues less easily accessible for analysis. However, a study of 8-oxodG levels in PBMC, tumour and normal human tissue, failed to show any correlation between the tissues and PBMC (Fokinski et al. 2000), warranting further investigation of this issue.

Study format. Double-blind cross-over studies, normally reserved for pharmaceutical drug intervention trials, are rarely applied to the examination of antioxidant function in vivo. Invariably, antioxidant studies are of a longitudinal design, using subjects as their own controls, effectively accounting for physiological differences. This has clearly not prevented the acquisition of meaningful data, and in some instances has facilitated novel findings such as the postsupplementation effect, described earlier. Clearly it is important to use the most appropriate trial format which will vary depending on the hypothesis to be tested (Jones \& Payne, 1997).

\section{Conclusion}

The ability of fruit and vegetables to reduce the risk of cancer development does appear to have increasing epidemiological, if not experimental, support (Lee, 1999). The role of micronutrients in this effect, although not specifically antioxidants, has been extensively argued (Ames, 2001). However, it is not easy to agree with conclusions such as those by Duthie et al. (1996) that fruit and vegetables exert a cancer-protective effect via a decrease in oxidative DNA damage. Firstly, supplementation studies have failed to show conclusively that antioxidants alone can modulate cancer risk and second, the role of oxidative DNA damage in carcinogenesis has likewise not been conclusively demonstrated. Whilst the antioxidant effect of fruit and vegetables may be under question, evidence is growing that their constituents may affect gene expression and hence modulate DNA damage, either via DNA repair pathways (Lunec et al. 2000a) or enzymes associated with xenobiotic metabolism (Verhagen et al. 1995; Deng et al. 1998). Furthermore, it is very likely that antioxidants act jointly with other components in fruit and vegetables, and that it is this concerted effort which has a protective effect (Block, 1991). Overall, it would seem that a diet high in fruit and vegetables, along with the avoidance of known carcinogens, remains the current choice for maintenance of health.

\section{Acknowledgements}

The authors wish to acknowledge the following: Dr Jabeen Ahmad, Helen Waller and Amina Husseini from the Division of Chemical Pathology, and Linda Dickinson and Dr George DD Jones from the Biomolecular Damage Group (Centre for Mechanisms of Human Toxicity, University of Leicester). Financial support from the Ministry of Agriculture, Fisheries and

Food, Food Standards Agency, Arthritis Research Campaign and Scottish Office is gratefully acknowledged. 


\section{References}

Aherne SA \& O'Brien NM (2000) Mechanism of protection by the flavonoids, quercetin and rutin, against tert-butylhydroperoxide- and menadione-induced DNA single strand breaks in Caco-2 cells. Free Radical Biology and Medicine 29, 507-514.

Alam ZI, Jenner A, Daniel SE, Lees AJ, Cairns N, Marsden CD, Jenner P \& Halliwell B (1997) Oxidative DNA damage in the Parkinsonian brain: an apparent selective increase in 8-hydroxyguanine levels in substantia nigra. Journal of Neurochemistry 69, 1196-1203.

Alpha tocopherol, $\beta$-carotene Cancer Prevention Study Group (1994) The effect of vitamin E and $\beta$-carotene on the incidence of lung cancer and other cancers in male smokers. New England Journal of Medicine 330, 1029-1035.

Ames BN (2001) DNA damage from micronutrient deficiencies is likely to be a major cause of cancer. Mutation Research 475, 7-20.

Anderson D, Phillips BJ, Yu T-W, Edwards AJ, Ayesh A \& Butterworth KR (1997) The effects of vitamin C supplementation on biomarkers of oxygen radical generated damage in human volunteers with 'low' or 'high' cholesterol levels. Environmental and Molecular Mutagenesis 30, 161-174.

Angelis, KJ, Dusinskaa M \& Collins AR (1999) Single cell gel electrophoresis: Detection of DNA damage at different levels of sensitivity. Electrophoresis 20, 2133-2138.

Astley S, Langrish-Smith A, Southon S \& Sampson M (1999) Vitamin E supplementation and oxidative damage to DNA and plasma LDL in type I diabetes. Diabetes Care 22, 1626-1631.

Baysal E, Sullivan SG \& Stern A (1989) Prooxidant and antioxidant effects of ascorbate on tert-butylhydroperoxideinduced erythrocyte membrane damage. International Journal of Biochemistry 21, 1109-1113.

Beatty ER, O'Reilly JD, England TG, McAnilis GT, Young IS, Halliwell B, Geissler CA, Sanders TAB \& Wiseman H (2000) Effect of dietary quercetin on oxidative DNA damage in healthy human subjects. British Journal of Nutrition 84, 919-925.

Bianchini F, Elmstahl S, Martinez-Garcia C, van Kappel A-L, Douki T, Cadet J, Ohishima H, Riboli E \& Kaaks R (2000) Oxidative DNA damage in human lymphocytes: correlations with plasma levels of $\alpha$-tocopherol and carotenoids. Carcinogenesis 21, 321-324.

Bielski BHJ \& Richter HW (1975) Some properties of the ascorbate free radical. Annals of the New York Academy of Sciences 258, 231-237.

Block G (1991) Vitamin C and cancer prevention, the epidemiologic evidence. American Journal of Clinical Nutrition 53, 270S-282S.

Borek C (2001) Antioxidant health effects of aged garlic extract. Journal of Nutrition 131, 1010S-1015S.

Boyle SP, Dobson VL, Duthie SJ, Hinselwood DC, Kyle JAM \& Collins AR (2000a) Bioavailability and efficiency of rutin as an antioxidant: a human supplementation study. European Journal of Clinical Nutrition 54, 774-782.

Boyle SP, Dobson VL, Duthie SJ, Kyle JAM \& Collins AR (2000b) Absorption and DNA protective effects of flavonoid glycosides from an onion meal. European Journal of Nutrition 39, 213-223.

Brigelius-Flohe B \& Traber MG (1999) Vitamin E: function and metabolism. FASEB Journal 13, 1145-1155.

Brown RK, McBurney A, Lunec J \& Kelly FJ (1995) Oxidative damage to DNA in patients with cystic fibrosis. Free Radical Biology Medicine 18, 801-806.

Byers T \& Perry G (1992) Dietary carotenes, vitamin C, and vitamin E as protective antioxidants in human cancers. Annual Review of Nutrition 12, 139-159.

Cadet J, D'Ham C, Douki T, Pouget J-P, Ravanat J-L \& Sauvaigo S (1998) Facts and artifacts in the measurement of oxidative base damage to DNA. Free Radical Research 29, 541-550.

Cai Q \& Wei H (1996) Effect of dietary genistein on antioxidant enzyme activities in SENECAR mice. Nutrition and Cancer 25, 1-7.

Calzada C, Bruckdorfer KR \& Rice-Evans C (1997) The influence of antioxidant nutrients on platelet function in healthy volunteers. Atherosclerosis 128, 97-105.

Carr A \& Frei B (1999) Does vitamin C act as a pro-oxidant under physiological conditions? FASEB Journal 13, 1007-1024.

Carty JL, Bevan R, Waller H, Mistry N, Cooke M, Lunec J \& Griffiths HR (2000) The effects of vitamin C supplementation on protein oxidation in healthy volunteers. Biochemical Biophysical Research Communications 273, 729-735.

Casalini C, Lodovici M, Briani C, Paganelli G, Remy S, Cheynier V \& Dolara P (1999) Effect of complex polyphenols and tannins from red wine (WCPT) on chemically-induced oxidative DNA damage in the rat. European Journal of Nutrition 38, 190-195.

Chatterjee M (2001) Vitamin D and genomic stability. Mutation Research 475, 69-88.

Chen L, Boweb PE, Berezy D, Aryee F, Stacewicz-Sapuntzakis M \& Roley RE (1999) Diet modification affects DNA oxidative damage in healthy human. Free Radical Biology and Medicine 26, 695-703.

Choi SW, Kim YI, Weitzel JN \& Mason JB (1998) Folate depletion impairs DNA excision repair in the colon of the rat. Gut 43, 93-99.

Chow CK (1988) Interrelationships of cellular antioxidant defence systems. In Cellular Antioxidant Defence Mechanisms, pp. 217-237 [CK Chow, editor]. Boca Raton, FL: CRC Press.

Claycombe KJ \& Meydani SN (2001) Vitamin E and genomic stability. Mutation Research 475, 37-44.

Collins AR, Gedik CM, Olmedilla B, Southon S \& Bellizzi M (1998a) Oxidative DNA damage measured in human 
lymphocytes: large differences between sexes and between countries, and correlations with heart disease mortality rates. FASEB Journal 12, 1397-1400.

Collins AR, Olmedilla B, Southon S, Granado F \& Duthie SJ (1998b) Serum carotenoids and oxidative DNA damage in human lymphocytes. Carcinogenesis 19, 2159-2162.

Cooke MS, Evans MD, Herbert KE \& Lunec J (2000) Urinary 8-oxo-2'deoxyguanosine: source, significance and supplements. Free Radical Research 32, 381-397.

Cooke MS, Evans MD, Podmore ID, Herbert KE, Mistry N, Mistry P, Hickenbotham PT, Hussieni A, Griffiths HR \& Lunec J (1998) Novel repair action of vitamin C upon in vivo oxidative DNA damage. FEBS Letters 439, 363-367.

Cooke MS \& Lunec J (2002) Immunochemical detection of oxidative DNA damage. In Oxidative Stress and Aging: Advances in Basic Science, Diagnostics and Intervention, pp. 275-293 [RG Cutler and H Rodriguez, editors]. Singapore: World Scientific Publishing Company.

Cooke MS, Patel K, Ahmad J, Evans MD \& Lunec J (2001) Monoclonal antibody to single-stranded DNA: a potential tool for DNA repair studies. Biochemical Biophysical Research Communications 284, 232-238.

Crott JW \& Fenech M (1999) Effect of vitamin C supplementation on chromosome damage, apoptosis and necrosis ex vivo. Carcinogenesis, 20, 1035-1041.

Dandona P, Thusu K, Cook S, Snyder B, Makowski J, Armstrong D \& Nicotera T (1996) Oxidative damage to DNA in diabetes mellitus. Lancet 347, 444-445.

Deng X-S, Tuo J, Poulsen HE \& Loft S (1998) Prevention of oxidative DNA damage in rats by Brussels sprouts. Free Radical Research 28, 323-333.

Dizdaroglu M (1991) Chemical determination of free radical-induced damage to DNA. Free Radical Biology Medicine 10, 225-242.

Dizdaroglu M (1998) Facts about the artifacts in the measurement of oxidative DNA base damage by gas chromtography-mass spectrometry. Free Radical Research 29, 551-563.

Duthie SJ, Collins AR, Duthie GG \& Dodson VL (1997) Quercetin and muyricetin protect against hydrogen-peroxide induced DNA damage (strand breaks and oxidised pyrimidines) in human lymphocytes. Mutation Research Genetic Toxicology and Environmental Mutagenesis 393, 223-231.

Duthie SJ, Grant G \& Narayanan S (2000) Increased uracil misincorporation in lymphocytes from folate-deficient rats. British Journal of Cancer 83, 1532-1537.

Duthie SJ \& Hawdon A (1998) DNA instability (strand breakage, uracil misincorporation, and defective repair) is increased by folic acid depletion in human lymphocytes in vitro. FASEB Journal 12, 1491-1497.

Duthie SJ, Ma A, Ross MA, \& Collins AR (1996) Antioxidant supplementation decreases oxidative DNA damage in human lymphocytes. Cancer Research 56, 1291-1295.

Erhola M, Toyokuni S, Okada K, Tanaka T, Hiai H, Ochi H, Uchida K, Osawa T, Neiminen MM, Alho H \& Kellokumpu-Lehtinen P (1997) Biomarker evidence of DNA oxidation in lung cancer patients, association of urinary 8-hydroxy-2'-deoxyguanosine excretion with radiotherapy, chemotherapy and response to treatment. FEBS Letters 409, 287-291.

Evans MD, Cooke MS, Akil M, Samanta AK \& Lunec J (2000) Aberrant processing of oxidative DNA damage in systemic lupus erythematosus. Biochemical Biophysical Research Communications 273, 894-898.

Evans MD, Griffiths HR \& Lunec J (1997) Reactive oxygen species and their cytotoxic mechanisms. In Advances in Molecular and Cell Biology, vol. 20: Mechanisms of Cell Toxicity, pp. 25-73 [JK Chipman, editor]. Greenwich, CT: JAI Press.

Farinati F, Cardin R, Degan P, de Maria N, Floyd RA, van Thiel DH \& Naccarato R (1999) Oxidative DNA damage in circulating leukocytes occurs as an early event in chronic HCV infection. Free Radical Biology Medicine 27, 1284-1291.

Fenech M, Dreosti I \& Aitken C (1997) Vitamin E supplements and their effect on vitamin E status in blood and genetic damage rate in peripheral blood lymphocytes. Carcinogenesis 18, 359-364.

Floyd RA, Watson JJ, Wong PK, Altmiller DH \& Rickard RC (1986) Hydroxyl free radical adduct of deoxyguanosine, sensitive detection and mechanism of formation. Free Radical Research 1, 163-172.

Fokinski M, Kotzbach R, Szymanski W \& Olinski R (2000) The level of typical biomarker of oxidative stress 8hydroxy-2'-deoxyguanosine is higher in uterine myomas than in control tissues and correlates with the size of the tumour. Free Radical Biology Medicine 29, 597-601.

Fraga CG, Motchnik PA, Shigenaga MK, Helbock HJ, Jacob RA \& Ames BN (1991) Ascorbic acid protects against endogenous oxidative DNA damage in human sperm. Proceedings of the National Academy of Sciences USA 88, $11003-11006$.

Frenkel K, Karkoszka J, Glassman T, Dubin N, Toniolo P, Taioli E, Mooney LA \& Kato I (1998) Serum autoantibodies recognising 5-hydroxymethyl-2'-deoxyuridine. Cancer Epidemiology Biomarkers and Prevention 7, $49-57$.

Haegele AD, Gillette C, O'Neill C, Wolfe P, Heimendinger J, Sedlacek S \& Thompson HJ (2000) Plasma xanthophyll carotenoids correlate inversely with indices of oxidative DNA damage and lipid peroxidation. Cancer Epidemiology Biomarkers and Prevention 9, 421-425.

Halliwell B (1998) Can oxidative DNA damage be used as a biomarker of cancer risk in humans? Problems, resolutions and preliminary results from nutritional supplementation studies. Free Radical Research 29, 469-486.

Halliwell B (1999) Vitamin C: poison, prophylactic or panacea? Trends in Biochemical Sciences 24, $255-259$.

Halliwell B \& Gutteridge JMC (1989) Free Radicals in Biology and Medicine, 2nd ed., p. 543. Oxford: Clarendon Press. 
Hertog MGL, Vries A, Ocké A, Schouten A, Bas Bueno-de-Mesquita H \& Vehagen H (1997) Oxidative DNA damage in humans, comparison between high and low habitual fruit and vegetable consumption. Biomarkers 2, 259-262.

Hollman PCH \& Katan MB (1999) Health effects and bioavailability of dietary flavonols. Free Radical Research 31, S75-S80.

Honda M, Yamada Y, Tomonaga M, Ichinose H \& Kamihira S (2000) Correlation of urinary 8-hydroxy-2'-deoxyguanosine (8-OHdG), a biomarker of oxidative DNA damage, and clinical features of haematological disorders: a pilot study. Leukaemia Research 24, 461-468.

Hosomi A, Arita M, Sato Y, Kiyose C, Ueda T, Igarashi O, Arai H \& Inoue K (1997) Affinity for alpha-tocopherol transfer protein as a determinant of the biological activities of vitamin E analogues. FEBS Letters 409, 105-108.

Huang H-Y, Helzlsouer KJ \& Appel LJ (2000) The effects of vitamin C and vitamin E on oxidative DNA damage: results from a randomised controlled trial. Cancer Epidemiology, Biomarkers and Prevention 9, 647-652.

Inoue M, Osaki T, Noguchi M, Hirohashi S, Yasumoto K \& Kasai H (1998) Lung cancer patients have increased 8hydroxydeoxyguanosine levels in peripheral lung tissue DNA. Japanese Journal of Cancer Research 89, 691-695.

Jacob RA, Kelley DS, Pianalto FS, Swendseid ME, Henning SM, Zhang JZ, Ames BN, Fraga CG \& Peters JH (1991) Immunocompetence and oxidant defence during ascorbate depletion of healthy men. American Journal of Clinical Nutrition 54, 1302S-1309S.

Janssen YMW, van Houten B, Borm PJA \& Mossman BT (1993) Biology of disease. Cell and tissue responses to oxidative damage. Laboratory Investigation 69, 261-274.

Jaruga P, Zastawny TH, Skokowski J, Dizdaroglu M \& Olinski R (1994) Oxidative DNA base damage and antioxidant enzyme activities in human lung cancer. FEBS Letters 341, 59-64.

Jenkinson AM, Collins AR, Duthie SJ, Wahle GG \& Duthie GG (1999) The effect of increased intakes of polyunsaturated fatty acids and vitamin E on DNA damage in human lymphocytes. FASEB Journal 13, 2138-3142.

Johnson MK \& Loo G (2000) Effects of epigallocatechin gallate and quercetin on oxidative damage to cellular DNA. Mutation Research - DNA Repair 459, 211-218.

Jones RG \& Payne RB (1997) Clinical Investigation and Statistics in Laboratory Medicine, pp. 124-184. London: ACB Venture Publications.

Joshi R, Adhikari S, Patro BS, Chattopadhyay S \& Mukherjee T (2001) Free radical scavenging behaviour of folic acid: evidence for possible antioxidant activity. Free Radical Biology Medicine 30, 1390-1399.

Jovanovic SV, Clements D \& MacLeod K (1998) Biomarkers of oxidative stress are significantly elevated in Down's syndrome. Free Radical Biology Medicine 25, 1044-1048.

Kamal-Eldin A \& Appelqvist LA (1996) The chemistry and antioxidant properties of tocopherols and tocotrienols. Lipids 31, 671-701.

Kasai H \& Nishimura S (1986) Hydroxylation of guanine in nucleosides and DNA at the C-8 position by heated glucose and oxygen radical-forming agents. Environmental Health Perspectives 67, 111-116.

Lean MEJ, Noroozi M, Kelly I, Burns J, Talwar D, Sattar N \& Crozier A (1999) Dietary flavonols protect diabetic human lymphocytes against oxidative damage to DNA. Diabetes 48, 176-181.

Lee I-M (1999) Antioxidant vitamins in the prevention of cancer. Proceedings of the Association of American Physicians 111, 10-15.

Leinonen J, Lehtimäki T, Toyokuni S, Okada K, Tanaka T, Hiai H, Ochi HH, Laippala P, Rantalaiho V, Wirta O, Pasternack A \& Alho H (1997) New biomarker evidence of oxidative DNA damage in patients with non-insulindependent diabetes mellitus. FEBS Letters 417, 150-152.

Lenton KJ, Therriault H, Fulop T, Payette H \& Wagner JR (1999) Glutathione and ascorbate are negatively correlated with oxidative DNA damage in human lymphocytes. Carcinogenesis 20, 607-613.

Lezza AMS, Mecocci P, Cormio A, Flint Beal M, Cherubini A, Cantatore P, Senin U \& Gadleta MN (1999) Area-specific differences in $\mathrm{OH}^{8} \mathrm{dG}$ and $\mathrm{mtDNA}^{4977}$ levels in Alzheimer disease patients and aged controls. Journal of Antiaging Medicine 2, 209-216.

Lovell MA, Gabbita SP \& Markesbery WR (1999) Increased DNA oxidation and decreased levels of repair products in Alzheimer's disease ventricular CSF. Journal of Neurochemistry 72, 771-776.

Lowe GM, Booth LA, Young AJ, \& Bilton RF (1999) Lycopene and beta-carotene protect against oxidative damage in HT29 cells at low concentrations but rapidly lose this capacity at higher doses. Free Radical Research 30, 141-151.

Lunec J, Cooke MS, Podmore ID \& Evans MD (2000a) Modulation of in vivo DNA repair in humans by vitamin C supplementation. In Human Monitoring after Environmental and Occupational Exposure to Chemical and Physical Agents, pp. 68-75 [D Anderson and AE Karakaya, editors]. New York: Kluwer Academic/Plenum Publishers.

Lunec J, Herbert KE, Blount S, Griffiths HR \& Emery P (1994) 8-Hydroxydeoxyguanosine, A marker of oxidative DNA damage in systemic lupus erythematosus. FEBS Letters 348, 131-138.

Lunec J, Herbert KE, Jones GDD, Dickinson L, Evans M, Mistry N, Chauhan D, Capper G \& Zheng Q (2000b) Development of a quality control material for the measurement of 8-oxo-7,8-dihydro-2'-deoxyguanosine, an in vivo marker of oxidative stress, and comparison of results from different laboratories. Free Radical Research 33, S27-S31.

Lunec J, Podmore ID, Griffiths HR, Herbert KE, Mistry N \& Mistry P (1999) Effects of vitamin E supplementation on in vivo oxidative DNA damage. In Advances in DNA Damage and Repair, pp. 283-294 [M Dizdaroglu and AE Karakaya, editors]. New York: Kluwer Academic Press/Plenum Publishers.

Lyras L, Perry RH, Perry EK, Ince PG, Jenner A, Jenner P \& Halliwell B (1998) Oxidative damage to proteins, lipids and DNA in cortical brain regions from patients with dementia with Lewy bodies. Journal of Neurochemistry 71, $302-312$. 
Malins DC \& Haimanot R (1991) Major alterations in the nucleotide structure of DNA in cancer of the female breast. Cancer Research 51, 5430-5432.

Marnett LJ (2000) Oxyradicals and DNA damage. Mutation Research 21, 361-370.

Matsui A, Ikeda T, Enomoto K, Hosoda K, Nakashima H, Omae K, Watanabe M, Hibi T \& Kitajima M (2000) Increased formation of oxidative DNA damage, 8-hydroxy-2'-deoxyguanosine, in human breast tissue and its relationship to GSTP1 and COMT genotypes. Cancer Letters 151, 87-95.

Matsui M, Nishigori C, Toyokuni S, Takada J, Akaboshi M, Ishikawa M, Imamura S \& Miyachi Y (1999) The role of oxidative DNA damage in human arsenic carcinogenesis: detection of 8-hydroxy-2'-deoxyguanosine in arsenicrelated Bowen's disease. Journal of Investigative Dermatology 113, 26-31.

Michell JH \& Collins AR (1999) Effects of soy milk supplement on plasma cholesterol levels and oxidative DNA damage in men - a pilot study. European Journal of Nutrition 38, 143-148.

Murata M \& Kawanishi S (2000) Oxidative DNA damage by vitamin A and its derivative via superoxide generation. Journal of Biological Chemistry 275, 2003-2008.

Mussarat J, Arezina-Wilson J \& Wani AA (1996) Prognostic and aetiological relevance of 8-hydroxyguanosine in human breast carcinogenesis. European Journal of Cancer 32A, 1209-1214.

Noroozi M, Angerson WJ \& Lean MEJ (1998) Effects of flavonoids and vitamin C on oxidative DNA damage to human lymphocytes. American Journal of Clinical Nutrition 67, 1210-1218.

Okamoto H, Toyokuni S, Uchida K, Ogawa O, Takenewa J, Kakehi Y, Kinoshita H, Hattori-Nakakuki Y, Hiai H \& Yoshida O (1994) Formation of 8-hydroxy-2'-deoxyguanosine and 4-hydroxy-2-nonenal-modified proteins in human renal-cell carcinoma. International Journal of Cancer 58, 825-829.

Olinski R, Zastawny T, Budzbon J, Skokowski J, Zegarski W \& Dizdaroglu M (1992) DNA base modifications in chromatin of human cancerous tissues. FEBS Letters 309, 193-198.

Oliva MR, Ripoll F, Muniz P, Iradi A, Trullenque R, Valls V, Drehmer E \& Saez GT (1997) Genetic alterations and oxidative metabolism in sporadic colorectal tumours from a Spanish community. Molecular Carcinogenesis 18, $232-243$

Omenn GS, Goodman MD, Thornquist MD, Balmes J, Cullen MR, Glass A, Keogh JP, Meyskens FL, Valanis B, Williams JH, Barnhart S \& Hammar S (1996) Effects of a combination of $\beta$-carotene and vitamin A on lung cancer and cardiovascular disease. New England Journal of Medicine 334, 1150-1155.

Parker RS (1996) Absorption, metabolism and transport of carotenoids. FASEB Journal 10, 542-551.

Podmore ID, Cooper D, Evans MD, Wood M \& Lunec J (2000) Simultaneous measurement of 8-oxo-2' -deoxyguanosine and 8-oxo-2'deoxyadenosine by HPLC-MS/MS. Biochemical and Biophysical Research Communications 277, 764-770.

Podmore ID, Griffiths HR, Herbert KE, Mistry N, Mistry P \& Lunec J (1998a) Vitamin C exhibits pro-oxidant properties. Nature 392, 559.

Podmore ID, Griffiths HR, Herbert KE, Mistry N, Mistry P \& Lunec J (1998b) Does vitamin C have a pro-oxidant effect? Nature 395, 231-232.

Pool-Zobel BL, Aldercreutz H, Glei M, Liegibel UM, Sittlington J, Rowland I, Wahala K \& Rechkemmer G (2000) Isoflavonoids and lignans have different potentials to modulate oxidative genetic damage in human colon cells. Carcinogenesis 21, 1247-1252.

Pool-Zobel BL, Bub A, Muller H, Wollowski I \& Rechkemmer G (1997) Consumption of vegetables reduces genetic damage in humans: First results of a human intervention trial with carotenoid-rich foods. Carcinogenesis 18, 1847-1850.

Porkkala-Sarataho E, Salonen JT, Nyyssonen K, Kaikkonen J, Salonen R, Ristonmaa U, Diczfalusy U, Brigelius-Flohe R, Loft S \& Poulsen HE (2000) Long-term effects of vitamin E, vitamin C and combined supplementation on urinary 7-hydro-8-oxo-2'-deoxyguanosine, serum cholesterol oxidation products and oxidation resistance of lipids in nondepleted men. Ateriosclerosis, Thrombosis and Vascular Biology 20, 2087-2093.

Porrini M \& Riso P (2000) Lymphocyte lycopene concentration and DNA protection from oxidative damage is increased in women after a short period of tomato consumption. Journal of Nutrition 130, 189-192.

Poulsen HE, Loft S, Priemé H, Vistisen K Lykkesfeldt J, Nyyssonen K \& Salonen JT (1998) Oxidative DNA damage in vivo, relationship to age, plasma antioxidants, drug metabolism, glutathione-S-transferase activity and urinary creatinine excretion. Free Radical Research 29, 565-571.

Priemé H, Loft S, Nyyssönen, Salonen JT \& Poulsen HE (1997) No effect of supplementation with vitamin E, ascorbic acid, or coenzyme Q10 on oxidative DNA damage estimated by 8-oxo-7,8-dihydro-2'-deoxyguanosine excretion in smokers. American Journal of Clinical Nutrition 65, 503-507.

Proteggente AR, Rehman A, Halliwell B \& Rice-Evans CA (2000) Potential problems of ascorbate and iron supplementation: pro-oxidant effect in vivo? Biochemical and Biophysical Research Communications 277, 535-540.

Ravanat J-L, Duretz B, Guiller A, Douki T \& Cadet J (1998) Isotope dilution high-preformance liquid chromatographyelectrospray tandem mass spectrometry assay for the measurement of 8-oxo-7,8-dihydro- 2 '-deoxyguanosine in biological samples. Journal of Chromatography 715B, 349-356.

Rehman A, Bourne LC, Halliwell B \& Rice-Evans C (1999a) Tomato consumption modulates oxidative DNA damage in humans. Biochemical and Biophysical Research Communications 262, 828-831.

Rehman A, Collis CS, Yang M, Kelly M, Diplock AT, Halliwell B \& Rice-Evans C (1998) The effects of iron and vitamin C co-supplementation on oxidative damage to DNA in healthy volunteers. Biochemical and Biophysical Research Communications 246, 293-298. 
Rehman A, Nourooz-Zadeh J, Moller W, Tritschler H, Pereira P \& Halliwell B (1999b) Increased oxidative damage to all DNA bases in patients with type II diabetes mellitus. FEBS Letters 448, 120-122.

Rice-Evans C, Sampson J, Bramley PM \& Holloway DE (1997) Why do we expect carotenoids to be antioxidants in vivo? Free Radical Research 26, 381-398.

Rice-Evans CA, Miller NJ \& Paganga G (1996) Structure-antioxidant activity relationships of flavonoids and phenolic acids. Free Radical Biology and Medicine 20, 933-956.

Riso P, Pinder A, Santangelo A, \& Porrini M (1999) Does tomato consumption effectively increase the resistance of lymphocyte DNA to oxidative damage. American Journal of Clinical Nutrition 69, 712-718.

Romano G, Sgambato A, Mancini R, Capelli G, Rosaria M, Flamini G, Boninsegna A, Vecchione A \& Cittadini A (2000) 8-Hydroxy-2'-deoxyguanosine in cervical cells: correlation with grade of dysplasia and human papillomavirus infection. Carcinogenesis 21 1143-1147.

Shigenaga MK, Gimeno CJ \& Ames BN (1989) Urinary 8-hydroxy-2'-deoxyguanosine as a biological marker of in vivo oxidative DNA damage. Proceedings of the National Academy of Sciences USA 86, 9697-9701.

Shimoda R, Nagashima M, Sakamoto M, Yamaguchi N, Hirohashi S, Yokota J \& Kasai H (1994) Increased formation of oxidative DNA damage, 8-hydroxydeoxyguanosine, in human livers with chronic hepatitis. Cancer Research 54, 3171-3172.

Sies H \& Stahl W (1995) Vitamins E and C, beta-carotene, and other carotenoids as antioxidants. American Journal of Clinical Nutrition 62, 1315S-1321.

Smith MJ, Inserra PF, Watson RR, Wise JA \& O’Neill KL (1999) Supplementation with fruit and vegetable extracts may decrease DNA damage in the peripheral lymphocytes of an elderly population. Nutrition Research 19, 1507-1518.

Stentürker S, Karahalil, B, Inal M, Yilmaz H, Muslumanoglu H, Gedikoglu G \& Dizdaroglu M (1997) Oxidative DNA base damage and antioxidant enzyme levels in childhood acute lymphoblastic leukaemia. FEBS Letters 416, 286-290.

Stocker R and Frei B (1991) Endogenous antioxidant defences in human blood plasma. In Oxidative Stress: Oxidants and Antioxidants, pp. 213-243 [H Sies, editor]. London: Academic Press.

Sumida S, Doi T, Sakurai M, Yoshioka Y \& Okamura K (1997) Effect of a single bout of exercise and beta-carotene supplementation on the urinary excretion of 8-hydroxy-deoxyguanosine in humans. Free Radical Research 27, $607-618$.

Tagesson C, Kallberg M, Klintenberg C \& Starkhammar H (1995) Determination of urinary 8-hydroxydeoxyguanosine by automated coupled-column high performance liquid chromatography: a powerful technique for assaying in vivo oxidative DNA damage in cancer patients. European Journal of Cancer 31A, 934-940.

Thompson HJ, Heimendinger J, Haegele A, Sedlacek SM, Gillette C, O’Neill P, Wolfe P \& Conroy C (1999) Effect of increased vegetable and fruit consumption on markers of oxidative cellular damage. Carcinogenesis 20, 2261-2266.

Torbergsen AC \& Collins AR (2000) Recovery of human lymphocytes from oxidative DNA damage; the apparent enhancement of DNA repair by carotenoids is probably simply an antioxidant effect. European Journal of Nutrition 39, 80-85.

Tsuboi H, Kouda K, Takeuchi H, Takigawa M, Masamoto Y, Takeuchi M \& Ochi H (1998) 8-Hydroxydeoxyguanosine in urine as an index of oxidative damage to DNA in the evaluation of atopic dermatitis. British Journal of Dermatology 138, 1033-1035.

Verhagen H, Poulsen HE, Loft S, van Poppel G, Willems MI \& van Bladeren PJ (1995) Reduction of oxidative DNAdamage in humans by Brussels sprouts. Carcinogenesis 16, 969-970.

Vojdani A, Bazargan M, Vojdani E \& Wright J (2000) New evidence for the antioxidant properties of vitamin C. Cancer Detection and Prevention 24, 508-523.

Vulimiri SV, Wu X, Baer-Dubowska W, de Andrade M, Detry M, Spitz MR \& DiGiovanni J (2000) Analysis of aromatic DNA adducts and 7,8-dihydro-8-oxo-2'-deoxyguanosine in lymphocyte DNA from a case-control study of lung cancer involving minority populations. Molecular Carcinogenesis 27, 34-46.

Witt EH, Reznick AZ, Viguie CA, Starke-Reed P \& Packer L (1992) Exercise, oxidative damage and effects of antioxidant manipulation. Journal of Nutrition 122, 766-773.

Woods JA, Bilton RF \& Young AJ (1999) Beta-carotene enhances hydrogen peroxide-induced DNA damage in human hepatocellular HepG2 cells. FEBS Letters 449, 255-258.

World Cancer Research Fund/American Institute for Cancer Research (1997) Food, Nutrition and the Prevention of Cancer: a Global Perspective. Washington, DC: American Institute for Cancer Research.

Yamamoto T, Hosokawa K, Tamura T, Kanno H, Urabe M \& Honjo H (1996) Urinary 8-hydroxy-2'-deoxyguanosine (8-OHdG) levels in women with or without gynaecologic cancer. Journal of Obstetrics and Gynaecology 22, 359-363.

Yeh SL \& Hu ML (2000) Antioxidant and pro-oxidant effects of lycopene in comparison with beta-carotene on oxidantinduced damage in Hs68 cells. Journal of Nutritional Biochemistry 11, 548-554.

Zhang J, Perry G, Smith MA, Robertson D, Olson SJ, Graham DG \& Montine TJ (1999) Parkinson's disease is associated with oxidative damage to cytoplasmic DNA and RNA in substantia nigra neurons. American Journal of Pathology 154, 1423-1429.

Zhang P \& Omaye ST (2001) DNA strand breakage and oxygen tension: effects of beta-carotene, alpha-tocopherol and ascorbic acid. Food and Chemical Toxicology 39, 239-246. 


\section{NEW BOOK}

\section{INFORMATION}

From

\section{CABI PUBLISHING}

\section{Readership}

Veterinarians, progressive farmers, animal scientists and advanced students of nutrition.

\section{Description}

This book is an up to date reference book covering all aspects of macro and trace element nutrition in farm livestock. Sufficient information is given on metabolism, functions and interactions to explain why needs, feeds and imbalances are not always easy to define or anticipate. The major emphasis is on the mineral nutrition of ruminant livestock since they are most likely to be affected by imbalances but where pigs and poultry are the more vulnerable, extensive coverage of the non-ruminant is given.

\section{To view full contents or to order online please visit www.cabi-publishing.org/bookshop}

Postage \& Packing: For pre-paid orders in the UK, please add $£ 2.75$ for the Ist book and 60p for each additional book ordered (up to max. of 10). For pre-paid orders elsewhere, please add $£ 4.00$ for the Ist book and $£ \mid .00$ for each additional book. For orders not pre-paid, postage and packing will be charged according to the weight of the book.
CABI Publishing, CAB International

Wallingford,

Oxon OXIO 8DE, UK

Tel: +44 (0) I49। 832 I I I

Fax: +44(0)।49| 829292

Email: orders@cabi.org
CABI Publishing, CAB International

10 East 40th Street, Suite 3203, New York, NY I0016, USA Tel: + I 212 48I 7018 Fax: + I 2126867993

Email: cabi-nao@cabi.org 